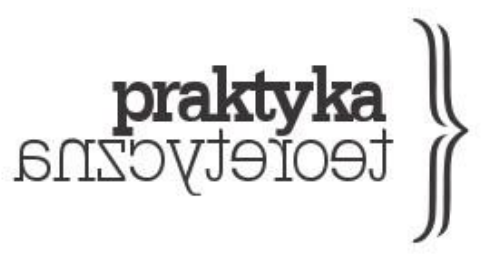

ISSN 2081-8130

DOI: $10.14746 /$ prt.2019.1.1 www.praktykateoretyczna.pl

\title{
ANTI-COMMUNISM IS ALL AROUND US
}

\author{
JODI DEAN
}

\begin{abstract}
The essay discusses four theses on contemporary anti-communism: 1) anticommunism is general and international; 2) anti-communism is an operator within capitalist ideology; 3) anti-communism is a politics of fear; 4) anti-communism is a lure that communists should reject. It proposes new theoretical framework to understand and contest many-faced manifestations of anti-communism.
\end{abstract}

Keywords: anti-communism, critique of ideology, politics of fear, far-right politics 
This essay makes four points:

1. Anti-communism is general and international;

2. Anti-communism is an operator within capitalist ideology;

3. Anti-communism is a politics of fear;

4. Anti-communism is a lure that communists should reject.

\section{Anti-communism is international}

A quick glance around the world reveals the international dimension of anti-communism. We find it in Bolsonaro's winning campaign for the presidency of Brazil and Duterte's presidency of the Philippines. We see it in Indian Prime Minister's Narendra Modi's Hindu nationalism as well as the intensified nationalisms of ruling parties in Hungary and Poland. Anti-communism's international is significant because it tells us that anti-communism cannot be reduced to its specific national histories - which would repeat the nationalist gesture. Anti-communism is not simply a response by countries of the former East bloc to decades of Soviet domination. It is more than a constitutive feature of politics in the United States, with its ever-recurring Red Scares.

In fact, anti-communism has never been a strictly domestic or national phenomenon. We might note here perennial US imperialism, carried out as a defense of democracy from the Red Menace. We can observe as well the opposition of colonizing powers to anti-colonial revolution. And we might include the global networks of commercial and political elites as they conjoin and amplify opposition to communism, thirty years after its ostensible demise.

One might object that anti-communism signifies different things. It's one thing in Poland and something else entirely in the US and Brazil. This objection is unsatisfying. It fails to account for why "different things" are designated by the same signifier. So, yes, one can attend to historical and contextual differences, but it's crucial today, when we must build a new international communism, to draw out the general features of anti-communism. How do we explain anti-communism's persistence? What accounts for the broadness of anti-communism now?

A possible answer is that communism itself is and has always been international. There have been communist struggles all over the world. The fact that there are struggles means that there are opponents, which means that there are anti-communists. But this is not a very satisfying explanation. It assumes that anti-communism is part of a real existing struggle against powerful and popular communist parties. It suggests, in other words, a kind of empirical basis for anti-communism, as if anti-communism were a response to a real existing empirical threat. But that can't account for contemporary anti-communism in the US, Europe, and Brazil, where there is not an organized and powerful communist movement. Communism was never 
powerful enough to pose a threat to capitalist state power in the US state and it was defeated in the Soviet Union and its European sphere of influence.

Another possible explanation for the continuity of anti-communism nearly thirty years after the end of state socialism is that it's a remnant of old struggles. People who once really fought against communism can "keep wearing the old clothes", playing off of the same script, deploying the old rhetoric in hope of inciting past feelings. The rhetoric works regardless of context, of history. It's a name standing it for a symbol, a nugget of affect without symbolic efficiency - it could mean anything.

This answer could draw support from The Communist Manifesto - Marx and Engels note how all sorts of different forces accuse their opponents of being communists - even when they are not. That's what they mean when they call communism a specter that haunts Europe. The idea of communism has power, it has force, such a force that parties fight their opponents by trying to tarnish them as communists.

Alas, this response, too, is not altogether satisfying - because communism is not completely absent of content, especially not after Marx and Engel's famous manifesto filled it out and revolutionary struggle gave it a body. Communism is a name for the political struggle of the working class and oppressed, the struggle against property and exploitation and for equality, justice, and freedom from the dictates of bosses, landlords, owners, and banks. Anticommunism isn't just an empty gesture and way to demonize opponents. It indicates an opposition to equality, the rejection of the idea of collective labor for collective benefit. The rhetoric without context charge erases this emancipatory content, the fact of real historical and ongoing struggles. In so doing, it again repeats the right-wing, neo-fascist and liberal gesture because of course the far Right are not the only anti-communists. Liberals and social democrats join them in legitimating anti-communism. Liberal anti-communism and fascist anticommunism go hand in hand. And they do so for the same reasons: to protect capitalism.

\section{Anti-communism is the ideology of capitalism}

Because communism is the one ideology, the one ideal, that anchors itself in the abolition of private property, exploitation, and production for the sake of capital accumulation, capitalism has to oppose it. Communism is that modern ideology always and everywhere on the side of the oppressed. When labor is strong, when those who have been racially, sexually, ethnically, and colonially oppressed become more visible, more organized, and more militant, anticommunism intervenes to set up barricades. Anti-communism thus serves to structure the political field by establishing the terrain of possibility: what is available, what is off the table, what is impossible - unthinkable. And notice, even as anti-communism claims that 
communism is itself impossible, it mobilizes social forces to oppose it. It fights against the impossible.

Once we recognize the broadness of anti-communism, that it's virtually everywhere, that it appears in all sorts of different empirical settings, and that it's oriented in opposition to what it claims to be impossible, we can see that anti-communism in general is not the result of an empirical analysis of communist power or the specific political strength of actual communists. Anti-communism is broader, more abstract, affective, and ideological - in other words, political. Anti-communism is a feature of the general setting of capitalism - and it has been since the $19^{\text {th }}$ century. That anti-communism is a feature of capitalism also means that there is a difference between internal critiques of communism, different strategies for building communism, criticisms of these strategies and so on and "anti-communism" - the latter is this general, ideological orientation or thread through which capitalism tries to immunize and protect itself.

Anti-communism is crucial to the maintenance of the fiction that there is no alternative to capitalism. Rhetorics of anti-communism wage unceasing war to make sure that collective benefit, cooperation, and planning are off the table, suspect, impossible. The violence of capitalism disappears as communism is made into the one repository of all historical violence. We see this in the present (as in Hungary and Poland) where the extreme policies of parties that want to maintain capitalism are attributed to residual communism rather than recognized as the strongman authoritarianism long part of the far Right, rather than acknowledged, in other words, as capitalist authoritarianism, the authoritarianism that the Right uses to force an order into capitalism's disorder. Instead of the disorder of competition, markets, innovation, prices, dispossession, foreclosure, debt, and imperialist war, in capitalist authoritarianism disorder is foreign - the refugee, the immigrant, the black, the Muslim, the Jew. Or it is disorder itself, disorder without cause, that is the problem anti-communists want to address - women out of place, sex out of place, sexuality out of place, the young and the poor refusing to stay in their place. Dramatic changes in conditions of work, in the character of communities and life that accompany disruptive and ubiquitous technology, urbanization and rural depopulation, shifts from industry and manufacture to financial services, exodus of the labor force as young people look for better futures, the increase in the number of women in the paid economy all become a disorder to be dealt with by the assertion of order, church, police, family, and race. Anti-communism is the lynchpin of this assertion. The arsenal of anti-communism asserts religion, family, and law and order - even as it promotes its own unlaw and disorder.

The anti-communist script is repeated to assert, over and over, that there is no alternative to capitalism, that no matter what else happens, the system remains. Capitalism will be supported and fortified. Capitalism is the ground of freedom and individuality - private 
property and choice. Capitalism's contradictions are denied, it's persistent immiseration exteriorized onto foreign and disordered bodies.

\section{Anti-communism is a politics of fear}

Anti-communism mobilizes fear and anxiety. It condenses the real fears and anxieties of those living under capitalism and displaces them onto the fantastic figure of a communist threat the specter haunting Europe. This condensation and displacement gives moral dignity and political drama to hate. To be against racial and ethnic minorities, to want to put women in their place is not just bigotry, it's not backwards and misogynistic. Rather, it has moral and political dignity as part of a world historical struggle against communism. Even national preference becomes internationalized, again worthy of admiration because of its role in the battle against infernal communism. To use one example: as Yasuhiro Katagiri (2014) documents and demonstrates, anti-communism in the US has been historically allied with segregation. After the McCarthy era hearings and show trials came to an end, professional anticommunists went to the US south to help organize against de-segregation, against Civil Rights, and in support of the old Jim Crow apartheid system. They worked to spread the sense that to support civil rights was to support communism. Even Martin Luther King, Jr. was excoriated as a communist. In an effort to appear as more than just racist, the defense of segregation used anti-communism to give itself moral legitimacy. To be sure, this "legitimacy" was clearly false and incoherent - an inversion of victimization where white people are the victims, not African Americans who are lynched and denied the right to vote. And the new victim status of whites is turned into its own weird kind of heroism: as heroes of anti-communist resistance entitled to respect and dignity. In sum, what's crucial to recognize here is the work of an underlying fantasy structure - anti-communism is not an empirical argument against a specific program but rather the mobilization of a politics of fear (Robin 2004).

Another way that the politics of fear operates is through the eclipse of the present by the past. Rather than dealing with problems in the present (such as climate change and dramatic inequality), the political battle is displaced into the past - hence, the drama around monuments and museums, the reconstruction of historical memory. Anti-communism addresses present fear by shifting focus onto the past and legitimating itself with reference to this past. As Slavoj Žižek pointed out over twenty years ago, this memory politics is not about commemorating the dead. It's a way that leaders try to legitimate themselves as continuers of the work of the dead. The dead are their redeemers (Žižek 1993, 194).

Anti-communism mobilizes a fear of loss, of theft, a fear that what you have will be taken from you. This mobilization conceals the absence of property, of wealth, of job security, of success, of sovereignty, of freedom. It posits that we have them by positioning them as stolen 
possessions (Žižek 1993, 201-205). It's like, communism is what prevents you from being rich, widely admired, having lots of sex, and so on. This of course obscures the fact that the reality under capitalism is that one percent of the people have eighty-two percent of the world's annual wealth; eight men have the wealth of half the planet, etc. ${ }^{1}$ By positing communism as a source of deprivation, as an ideology based on taking away your property, anti-communism conceals the fact that you don't actually have any property to begin with. At the same time, it provides the affective sense that the Right gives and the Left takes.

\section{Anti-communism is a lure that communists should reject}

Today it seems that anti-communism generates more fascination than communism. People seem to find it more interesting to focus on the renewed power of the far Right, of nationalism and fascism, than on the challenge of renewing and reinvigorating communism for our time. People -left and right - are captivated by Bolsonaro, by Trump and his former henchman, Steve Bannon. They are preoccupied with far Right's explicit illiberalism in Poland and Hungary, the openly fascist forces appearing in Germany and Italy. It's like what really captures the popular imagination is the freedom to hate, the permission to break the rules, to refuse the demands of hospitality, civility, mutual respect, and solidarity and to grab what one can. The more plausible the link to Hitler, the greater the fascination the anti-communist attracts.

This fascination is particularly powerful in the affective networks of communicative capitalism where outrage circulates more quickly and easily than long-form analysis (see Dean 2010). People are more likely to read and share something that is short and outrageous, something that they think others are likely to share, than they are something that is long and complicated (see Dean 2016). Who has time?

But there's more to the affective charge of outrageous nationalists. Another dimension concerns the way they express the extremes of the capitalist system that liberal democracy wants to disavow. Trump, for example, is at one and the same time the emblem of the system and its disavowed core - disregard for law and norms and total focus on the accumulation of capital - that's his point: there's no faux-civilized veneer of dignity, custom, respect; why bother? For those with sufficient wealth and power, there is no penalty for violating norms, changing the rules (Dean 2015). Trump proves that the system is as bad as its left critics have always said that it is. He tells us what we know. The excesses of Trump and other oligarchs challenge conventional norms, break with a certain establishment, but they don't break with its capitalist underpinnings. Instead, they deliver on its promises, providing the excess that many

\footnotetext{
1 "Richest 1 percent bagged 82 percent of wealth created last year - poorest half of humanity got nothing", Oxfam International (22 January 2018), https://www.oxfam.org/en/pressroom/pressreleases/2018-0122/ richest-1-percent-bagged-82-percent-wealth-created-last-year.
} 
thought they would get and think they have earned. The excesses of these oligarchs announce that the benefits of capitalism are for those strong enough to take them, men strong enough to fight against those who would steal their enjoyment, the thieving immigrants, the racial and sexual others, the communists. For anti-communists, the willingness to violate norms, to be strong and put things in their place, grounds the legitimation of inequality - only the strong survive.

Žižek argues that powerless fascination bears witness to an encounter with the Real of enjoyment (where "enjoyment", jouissance, is that intense pleasure-pain that one can neither obtain nor escape) (Žižek 1993, 207). Anti-communism commands an enjoyment of inequality, an enjoyment of hierarchy, of making suffer. On the one hand is the anti-communist's preoccupation with death, with famine and camps and body counts. The numbers provide a veneer of morality and facticity even as they distort the histories to which they claim to bear witness. On the other side is anti-communism's own violence: this lets us see that its preoccupation with the power and excess of former state socialist regimes isn't critical - it's envious. Anti-communists don't reject extreme use of state power. They desire it and they encourage their followers to desire it, to claim it. Anti-communism gives permission to enjoy extreme power - at the same time that the contemporary Left critiques, mourns, and rejects it.

To the extent that Left criticism of anti-communism - or nationalism, or fascism, or authoritarianism, or Trump - remains captivated by it, the Left is invested in the same fantasy structure as the Right. It gets off on its outrage, on the Other's power, on its own incapacity or passivity. What's crucial, then, is breaking the hold of authoritarian enjoyment. How?

The Left needs to be the communists the Right fears. Such a move of identification occasions the practical work of building power. Rather than power being the object of a fantasy, it's a capacity to be built and exercised. When we focus on building capacity - a challenging prospect - we diminish the hold of the fascinating Right and turn instead to actual political work. This has an additional benefit of shifting our attention away from the superficial enemy - anti-communism - and toward the fundamental one - capitalism. This amplifies our sense of the urgency of practical work, inciting us to consider how, exactly, do we build a new communist movement able to defeat capitalism and provide a compelling alternative.

It's easier to remain captivated by fascist power than it is to work out real alternatives and build the collectivity that can make them happen. No wonder, then, that the Right is able to garner support from some of global capitalism's losers: it offers them (at least superficially) a kind of dignity or respect. It offers them a vision - of a glorious past. It offers them a solution - restore order and you can get what you want. It's harder to say now what the Left offers in any strong and clear sense, which means that the far Left (as small as we are) are basically saying: bite the hands that feed you; rise up, reject capitalism and... do what? More of the same? It's clear that liberal democracy cannot handle the current situation. Until we have a clear 
and compelling answer, anti-communism in all its rage and violence will be more powerful than communism, which means exploitation, oppression, and inequality triumph over production based on need, justice, and equality. Something generally beats nothing. In many places, the divide is between rural and urban (an old Marxist theme). People in rural areas feel abandoned - often literally because their communities are shrinking as their children move to the cities for opportunities. But rather than being a reason for despair, this should be an opportunity - if we have the will to take it. 


\section{References}

Dean, Jodi. 2010. Blog Theory. London: Polity Press.

Dean, Jodi. 2015. "Donald Trump Is the Most Honest Candidate in American Politics Today". In These Times, 12 August.

Dean, Jodi. 2016. "Faces as Commons: The Secondary Visuality of Communicative Capitalism". Onlineopen.org, 31 December.

Katagiri, Yashuhiro. 2014. Black Freedom, White Resistance, and Red Menace: Civil Rights and Anticommunism in the Jim Crow South. Baton Rouge: Louisiana State University Press.

Robin, Corey. 2004. Fear: The History of a Political Idea. New York: Oxford University Press.

Žižek, Slavoj. 1993. Tarrying with the Negative. Durham: Duke University Press. 
Jodi Dean - American political theorist and professor in the Political Science department at Hobart and William Smith Colleges in New York state. Emphasizing the use of Leninism, psychoanalysis, and certain postmodernist theories, Dean has made contributions to political theory, media studies and third-wave feminism, most notably with her theory of communicative capitalism - the online merging of democracy and capitalism into a single neoliberal formation that subverts the democratic impulses of the masses by valuing emotional expression over logical discourse. Her latest books included Crowds and Party (London-New York: Verso 2016) and The Communist Horizon (London-New York: Verso 2012).

\section{ADDRESS:}

Department of Political Science

Stern Hall

Geneva, NY 14456

EMAIL: jdean@hws.edu

Citation: Dean, Jodi. 2019. „Anti-communism is all around us”. Praktyka Teoretyczna 1(31): 15-24.

DOI: $10.14746 /$ prt.2019.1.1

AUTOR: Jodi Dean

TYTUŁ: Antykomunizm jest wszędzie wokół nas

ABSTRAKT: Prezentowany esej przedstawia cztery tezy na temat współczesnego antykomunizmu: 1) antykomunizm jest powszechny i międzynarodowy; 2) antykomunizm to narzędzie ideologii kapitalistycznej; 3) antykomunizm to polityka strachu; 4) antykomunizm to pokusa, którą powinni odrzucić komuniści. Proponuje też nowa ramę teoretyczną umożliwiającą zrozumienie i kwestionowanie różnorodnych manifestacji antykomunizmu.

SŁOWA KLUCZOWE: antykomunizm, krytyka ideologii, polityka strachu, polityka skrajnej prawicy 